\title{
SISTEM INFORMASI ADMINISTRASI CAFÉ \& RESTO BERBASIS WEB
}

\author{
Heri Yanto ${ }^{1}$, Firdaus ${ }^{2}$ \\ ${ }^{1}$ Universitas Putra Indonesia YPTK, Padang \\ E-mail: dimazheriyanto@gmail.com \\ ${ }^{2}$ Universitas Putra Indonesia YPTK, Padang \\ E-mail: firdaus@upiyptk.ac.id
}

\begin{abstract}
Pada masa pansemi saat ini pola arah pangsa pasar telah berubah, sistem pemasaran harus mengikuti tren dan melakukan pembaharuan, salah satunya adalah menggunakan sistem informasi. Salah satu restoran yang menjadi objek penelitianpeneliti saat ini adalah Profesional Resto \& Cafe. Profesional Resto \& Cafe merupakan sebuah usaha yang bergerak dalam bidang kuliner yang menjual makanan dan minuman khas daerah serta menu makanan yang sedang berkembang dikalangan masyarakat sekarang. Proses pemesanan makanan yang dilakukan masih secara manual yaitu menggunakan pulpen dan kertas. Pada umumnya restoran mengalami kesulitan untuk melayani pemesanan menu makanan dan minuman, kesulitan tersebut adalah pelanggan menunggu terlalu lama untuk mendapatkan menu makanan dan minuman yang di pesan. Selain itu pelayan juga mengalami kesulitan ketika menanyakan pesanan menu dari pelanggan yang dicatat secara manual dikertas. Pencatatan pesanan menu secara manual kurang efisien dari sisi waktu. Maka dari itu diperlukan suatu sistem yang dapat membantu meringankan pelanggan dalam memesan makanan dan minuman serta pelayan tidak menggunakan kertas dan pulpen untuk menanyakan pesanan dari pelanggan.
\end{abstract}

Keyword : Sistem Informasi, Administrasi, café\& Resto, Web

\section{PENDAHULUAN}

Tidak dapat dipungkiri bahwa teknologi sudah masuk di segala bidang untuk mempermudah pekerjaan yang akan di lakukan oleh seseorang yang bertanggung jawab pada bidang tersebut. Khususnya dalam bidang bisnis, perkembangan teknologi menawarkan kemudahan bagi pelaku bisnis dalam melakukan pekerjaan.

Salah satu restoran yang menjadi objek penelitian adalah Profesional Resto \& Cafe. Profesional Resto \& Cafe merupakan sebuah usaha yang bergerak dalam bidang kuliner yang menjual makanan dan minuman khas daerah serta menu makanan yang sedang berkembang dikalangan masyarakat sekarang. Proses pemesanan makanan yang dilakukan masih secara manual yaitu menggunakan pulpen dan kertas. Pada umumnya restoran mengalami kesulitan untuk melayani pemesanan menu makanan dan minuman, kesulitan tersebut adalah pelanggan menunggu terlalu lama untuk mendapatkan menu makanan dan minuman yang di pesan. Selain itu pelayan juga mengalami kesulitan ketika menanyakan pesanan menu dari pelanggan yang dicatat secara manual dikertas. Pencatatan pesanan menu secara manual kurang efisien dari sisi waktu. Maka dari itu diperlukan suatu sistem yang dapat membantu meringankan pelanggan dalam memesan makanan dan minuman serta pelayan tidak menggunakan kertas dan pulpen untuk menanyakan pesanan dari pelanggan..

\section{TINJAUAN LITERATUR}

Sistem informasi bukan hal yang baru. Yang baru adalah komputerisasinya. Sebelum ada komputer, teknik penyaluran informasi yang memungkinkan manajer merencanakan serta 
mengendalikan operasi yang telah ada. Komputer menambahkan satu atau dua dimensi, seperti kecepatan, ketelitian dan penyediaan data dengan volume yang lebih besar yang memberikan bahan pertimbangan yang lebih banyak untuk mengambil keputusan (Sutabri,Tata, 2012).

\section{Defenisi Sistem}

Secara sederhana sistem dapat di artikan sebagai suatu kumpulan atau himpunan dari unsur, komponen, atau variable yang tergorganisasi, saling berinteraksi, saling tergantung satu sama lain dan terpadu.

\section{Karakteristik Sistem}

Suatu sistem bisa dikatakan sebagai sebuah sistem informasi apabila memenuhi karakteristik utama dari sebuah sistem informasi. Berikut ini adalah beberapa karakteristik yang dimiliki oleh sistem informasi sebagai berikut.

\section{a. Komponen Sistem (Components)}

Suatu sistem terdiri dari sejumlah komponen-komponen yang saling berinteraksi, yang artinya saling bekerja sama membentuk suatu kesatuan. Komponen-komponen sistem tersebut dapat berupa suatu bentuk subsistem. Setiap subsistem memiliki sifat dari sistem yang menjalankan suatu fungsi tertentu dan mempengaruhi proses sistem secara keseluruhan.

\section{b. Batasan Sistem (Boundary)}

Ruang lingkup sistem merupakan daerah yang membatasi antara sistem dengan sistem yang lain atau sistem dengan lingkungan luarnya. Batasan sistem ini memungkinkan suatu sistem dipandang sebagai satu kesatuan yang tidak dapat dipisahkan.

c. Lingkungan Luar Sistem (Environment)

Bentuk apapun yang ada diluar ruang lingkup atau batasan sistem yang mempengaruhi operasis sistem tersebut disebut lingkungan luar sistem. Lingkungan luar sistem ini dapat bersifat menguntungkan dan dapat juga bersifat merugikan sistem tersebut.

d. Penghubung Sistem (Interface)
Media yang menghubungkan sistem dengan subsistem lain disebut penghubung sistem atau interface.Penghubung ini memungkinkan sumber-sumber daya mengalir dari satu subsistem ke subsistem lain. Bentuk keluaran dari suatu subsistem akan menjadi masukan untuk subsistem lain melalui penghubung tersebut.

e. Masukan Sistem (Input)

Energi yang dimasukan ke dalam sistem disebut masukan sistem, yang dapat berupa pemeliharaan (maintenance input) dan sinyal (signal input). Contoh, didalam suatu unit sistem komputer, "program" adalah maintenance input yang digunakan untuk mengoperasikan komputernya dan "data" adalah signal input untuk diolah menjadi informasi.

\section{f. Keluaran Sistem (Output)}

Hasil energi yang diolah dan di klasisfikasikan menjadi keluaran yang berguna. Keluaran ini merupakan masukan bagi subsistem yang lain seperti informasi. Keluaran yang dihasilkan adalah informasi. Informasi ini dapat digunakan sebagai masukan untuk pengambilan keputusan atau hal-hal lain yang menjadi input bagi subsistem lain.

\section{g. Pengolahan Sistem (Proccess)}

Suatu sistem dapat mempunyai suatu proses yang akan mengubah masukan menjadi keluaran.

\section{h. Sasaran Sistem (Object)}

Suatu sistem memiliki tujuan dan sasaran yang pasti dan bersifat deterministic. Kalau suatu sistem tidak memiliki sasaran maka operasi sistem tidak ada gunanya.Suatu sistem dikatakan berhasil bila mengenai sasaran dan tujuan yang direncanakan.

\section{METODOLOGI}

Untuk memberikan panduan dalam penyusunan penelitian ini maka perlu adanya metodologi penelitian dan kerangka kerja penelitian yang digunakan.Tempat yang penulis pilih sebagai lokasi penelitian dilubuk alung dengan alasan, karena di tempat tersebut banyak berbagai tempat kuliner yang memungkinkan banyak 
wisatawan domestic dari berbagai daerah yang ada di sumatera yang belum begitu mengenal wilayah tersebut.

Metode Pengumpulan Data

1. Wawancara (Interview)

Merupakan suatu cara pendekatan dengan melakukan kegiatan tanya jawab secara langsung dengan pihak-pihak yang bersangkutan sesuai dengan bidang yang diteliti untuk memperoleh informasi yang dibutuhkan. Ada pula pertanyaan - pertanyaan yang penulis ajukan yaitu sebagai berikut :
a. Kode Cafe \& Resto
b. Nama Cafe \& Resto
c. Alamat
d. Kelurahan
e. Kecamatan

2. Pengamatan langsung (Observasi) dan Dokumentasi

Dalam metode observasi dan dokumentasi ini digunakan untuk mempertahankan kebenaran ilmiah, sebagaimana telah ditegaskan oleh Gordon (1991), bahwa ; "Dasar - dasar pembatasan secara luas diterima oleh ilmuwan itu sendiri adalah kesaksian empirik, sebuah pernyataan adalah ilmiah jika diuji oleh observasi dan eksperimen" (Gordon, 1991). Metode observasi dan dokumentasi ini digunakan dalam rangka mengumpulkan data yang memberikan gambaran tentang situasi setempat atau social setting. Social setting diperoleh melalui observasi dan dokumentasi yaitu melihat data lapangan dan mendengar informasi dari informan, dan cerita warga setempat.

Metode observasi ini peneliti gunakan untuk memperoleh data yang berkaitan dengan Aspek yang meliputi :
a. Cafe \& Resto terdekat.
b. Siklus aktivitas masyarakat di Lubuk Alung.
c. Deskripsi ringkas lokasi penelitian.

Sedangkan Metode dokumentasi, digunakan untuk memperoleh data-data antara lain :

a. Keadaan geografis masyarakat daerah penelitian.

b. Data jumlah Cafe \& Resto yang penulis teliti.

c. Catatan - catatan lainnya yang relevan dengan permasalahan penelitian.

3. Penelitian Perpustakaan (Library Research)

Pada metode ini penulis melakukan pencarian bukubuku dan berbagai litetarur yang berhubungan dengan penelitian yang dilaksanakan sebagai bahan pedoman dalam perpustakaan.

\section{B. Pembuatan Pemodelan Aplikasi}

UML (Unified Modeling Language) merupakan metode pemodelan secara visual sebagai sarana untuk membantu dalam merancang dan membuat Sistem Informasi Cafe \& Resto ini. UML merupakan bahasa visual untuk pemodelan berorientasi objek. Dalam perancangan Sistem Informasi Cafe \& Resto berbasiskan web dapat diterapkan beberapa metode UML sehingga akan memudahkan dalam pendeskripsian dan desain aplikasi. 
1. Use Case Diagram

Agar dapat melihat hubungan (dependency) antara client module dan server module, kedua modul terebut dapat digabungkan menjadi satu bagian.

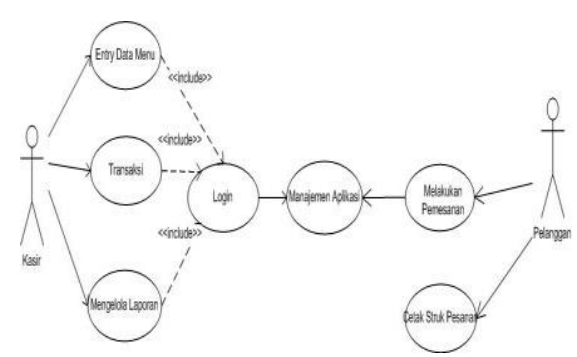

Gambar 1: Use Case Diagram Gabungan Pengguna dan Server pada Web

2. Class Diagram

Sequence diagram merupakan salah satu diagram Interaction yang menjelaskan bagaimana suatu operasi itu dilakukan berdasarkan pesan yang diterima dan ditangkap oleh actor sistem dari permintaan pesan user pada objek-objek interaksi.

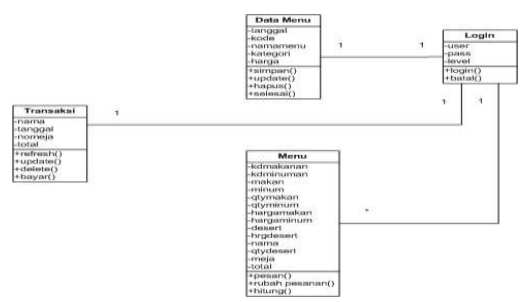

Gambar 2: Class Diagram

3. Deployment Diagram

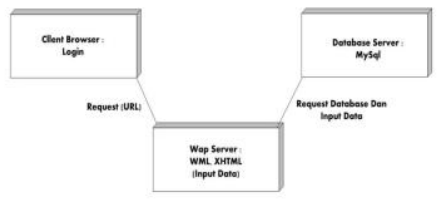

Gambar 3: Deployment Diagram

4. Perancangan Interface

Setelah semua data yang diperlukan dalam membangun sistem informasi penentuan tempat cafe \& resto didapatkan dan diinputkan dalam database maka selanjutnya akan dibuatkan desain interface yang berguna bagi user untuk mengakses halaman yang telah kita bangun.

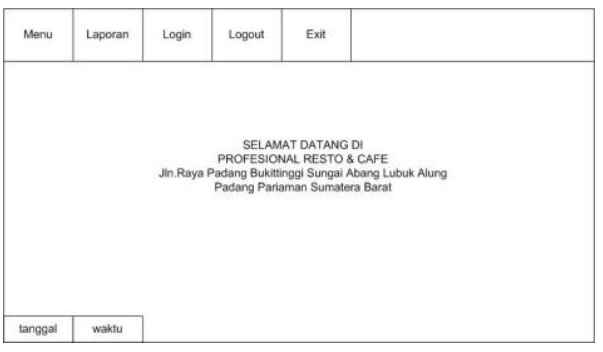

Gambar 4: Desain Menu Utama

\section{HASIL DAN DISKUSI}

Pada tampilan awal dari program setelah di jalankan adalah tampilan home. Sistem Informasi Cafe \& Resto berbasis web yaitu berguna untuk memberikan sebuah informasi Berikut ini user interface dan untuk keterangan masing-masing fungsi dan alat bantu akan dijelaskan selanjutnya.

\section{Tampilan Clien}

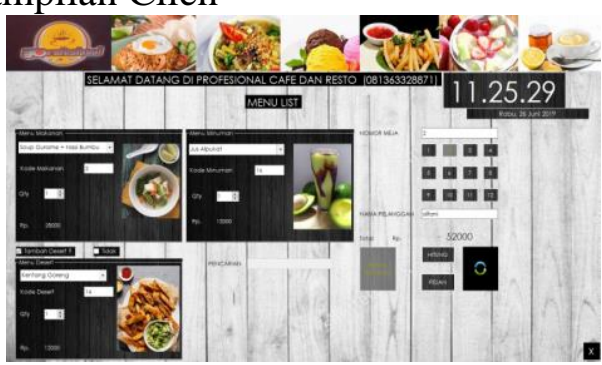

Gambar 5: Tampilan Menu Clien

2. Halaman Cetak Pesanan

Halaman ini digunakan untuk mencetak pesanan yang telah diinputkan dari pelanggan, data yang sudah dipesan bisa di akses oleh kasir untuk penghitungan total dari pesanan tersebut seperti gambar dibawah ini :




Gambar 6: Halaman Cetak Pesanan
3.Menampilkan InformasiPenjualan Halaman ini merupakan tampilan dari laporan transaksi penjualan yang ada pada Profesional Resto \& Cafe.

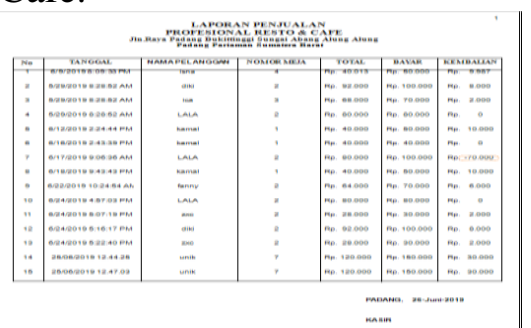

Gambar 7: Halaman Laporan Transaksi Penjualan

4.Tampilan Salah Halaman Transaksi Penjualan

Maka akan muncul informasi tentang objek tersebut beserta dengan halaman transaksi. Dapat dilihat pada gambar di bawah ini :

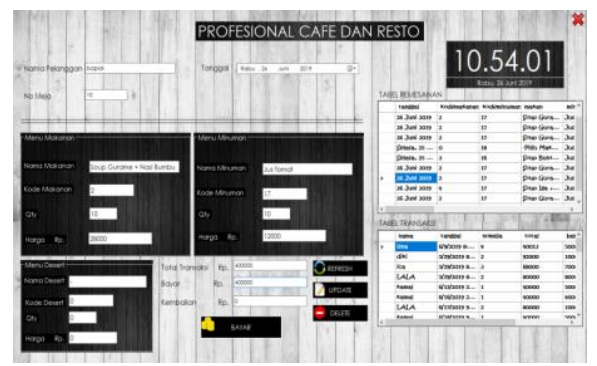

Gambar 8: Tampilan Salah Halaman Transaksi Penjualan

5. Tampilan Data Base



Gambar 9: Tampilan Data Base

\section{KESIMPULAN}

Berdasarkan hasil perancangan dan penerapan aplikasi dengan judul " Sistem Informasi Administrasi Resto \& Cafe Berbasis web", maka dapat diambil kesimpulan serta saran yang merupakan hasil dari penulisan laporan ini :

1. Sistem pemesanan menu makanan dan minuman secara manual pada Profesional Resto \& Cafe belum berjalan secara maksimal. Hal ini dapat dilihat dari lambatnya pelayanan karena keterbatasan daftar menu dan semua proses di lakukan secara manual.

2. Sistem pemesanan menu makanan dan minuman menggunakan komputer yang di terapkan pada Profesional Resto \& Cafe dapat berjalan secara efektif dan efisien tanpa harus menunggu lama untuk pelayan mencatat pesanan pelanggan.

3. Dengan adanya sistem pemesanan menu makanan dan minuman menggunakan program yang sudah tersedia di komputer, maka diharapkan administrasi dan pemesanan menu makanan dan minuman pada Resto \& Cafe dapat berjalan dengan baik dan lancar.

\section{DAFTAR PUSTAKA}

[1] Sugiri, dan Budi Kurniawan. 2007. Desain Web Menggunakan HTML Dan CSS. Yogyakarta: Andi Offset

[2] Pressman, Roger S.1997. Rekayasa Perangkat Lunak. Yogyakarta: Andi

[3] Aisah, K., Yanto, H., \& -, F. (2021). PERANCANGAN SISTEM INFORMASI APLIKASI E- 
LEARNING BERBASIS WEB DI SMA N 9 PADANG. Jurnal KomtekInfo, 8(1), 66-72.

[4] yanto, heri. (2018). SISTEM

PENDUKUNG KEPUTUSAN UNTUK

SELEKSI USULAN PENGAJUAN

SERTIFIKASI GURU

MENGGUNAKAN ALGORITMA K-

NEAREST NEIGHBOR BERBASIS

WEB. Jurnal KomtekInfo, 5(2), 42-50.

[5] Yanto,H.(2018).SISTEM

INFORMASI GEOGRAFIS TEMPAT

IBADAH BERBASIS WEB

MENGGUNAKAN ALGORITMA

FLOYD WARSHALL(STUDI

KASUS DI WILAYAH

MERANGIN).In Majalah Ilmiah INTI

(Vol.13).

[6] Yanto,H.(2018).OPTIMALISASI

JALUR

EVAKUASI

MENGGUNAKAN

SISTEM

INFORMASI GEOGRAFIS DIKOTA

PADANG BERBASIS WEB.Jurnal

Sains Dan Informatika, 4(2),193.

[7] Aini, A. 2007. Sistem Informasi Geografis Pengertian Dan Aplikasinya. Diakses

Dari http://stmik.amikom.ac.id/[Diakses 24 Maret 2013].

[8] Prahasta, Eddy. 2014. Sistem Informasi Geografis:Konsep Dasar Perspektif Geodesi \& Geomatika. Informatika, Bandung.

[9] MADCOM, 2005. Aplikasi Pemetaan Dan Database Dengan MapInfo Professional7.5. Andi, Yogyakarta.

[10]Yanto,H.(2018).OPTIMALISASI JALUR EVAKUASI MENGGUNAKAN SISTEM INFORMASI GEOGRAFIS DIKOTA PADANG BERBASIS WEB.Jurnal Sains Dan Informatika, 4(2),193. 